\title{
Great Powers and the Quest for Hegemony in the Contemporary International System
}

\author{
Monday E. Dickson, PhD \\ Department of Political Science, \\ Akwa Ibom State University, Obio Akpa Campus, Nigeria
}

\begin{abstract}
In global politics, the role as well as rise and fall of Great Powers, which often lead to the structural transformation in the international system have undoubtedly been at the heart of international political discourse. Soon after the Cold War, international system witnessed a transition from bipolar to unipolar system of hegemony, in which the United States-led Western coalition largely set and enforced the rules of the international order. However, later on, the global system eventually returned to a state of sharper and more explicit great-power competition. This study identifies states that vie for Great Power status in the contemporary world politics and explore their relative military, economic and other resources necessary for a state to be recognized as highly independent Great Power. The paper argues that although a number of states, particularly Russia, China, France and the United Kingdom and Germany represent global economic powers, American preponderance in each of the core components of state power - military, economic, political and technological, dwarf those of other nations. This has had far-reaching implications on the international system and the world at large. With the decline in the American hyper-supremacy, other nations should be able to duplicate the overall reach and influence of the United States - in terms of economic, military, political and technological powers. Hence, the polycentric world with several power centre will ensure stability in the contemporary world order.
\end{abstract}

Keywords: Great powers, post-Cold War Era, contemporary international system, rising powers,

\section{INTRODUCTION}

Since the Treaty of Westphalia in 1648 which, among other things, legitimized a commonwealth of sovereign States, marked the triumph of the stato in control of its internal affairs and independent externally and thus, represent the benchmark for the transformation of the international system from the medieval to modern form (Buzan \& Little, 1999, pp. 89104; Watson, 2009, p. 168). And in the overall discipline of International Relations (IR), the concept of Great Power occupies central position. In other words, Great Power system have been privileged object and subject of academic discourse and strategic planning. Consequently, great deal of attentions have been paid to identifying, classifying, explaining and understanding states that are considered Great Powers, as well as exploring the causes and consequences of relative rise and fall of such states in the international system. For instance, in the century between the Congress of Vienna and the outbreak of the World War I (WWI), international relations in Europe were largely dominated by five Great Powers: Austria (after 1867 Austria-Hungary), France, Great Britain, Prussia (after 1871 Germany) and Russia. During this period, the Great Powers jealously guarded their status and were at all times disinclined to admit new members into their ranks. They dominated the diplomacy and warfare of Europe and engaged in a series of lengthy coalition wars punctuated by swiftly changing alliances. The dominance of the five or six powers over such a long period gave an 
underlying stability to international relations. (Kennedy, 1987, p. xvii; Bridge \& Bullen, 2005, p.2).

At the outbreak of World War I (WWI), there were then eight Great Powers, of which for the first time two were located totally outside Europe - Austria, France, Germany, Great Britain, Italy Japan, Russia and the United States. The end of WWI found Austria, definitely and Germany and Russia temporarily removed from the list (Morgenthau, 1973, p.348) Consequently, WWI and its attendant political alignments triggered a process that eventually culminated in the integration of most of the world nations into a single balance of power system. Two decades later, at the outbreak of World War II (WWII), one could count seven Great Powers, Germany and the Soviet Union having again became first-rate powers and others having retained their status. The War, however, eliminated the Axis Power (Germany, Italy, and Japan) from major power status and significantly diminished the relative power of Great Britain and France, while China first appears on the list of major powers (Kaarbo and Ray, 2011, p.115). As put by Morgenthau (1973:349), the end of the Second World War saw Great Britain, the Soviet Union, and the United States as Great Powers, while China and France, in view of their past or their potentialities, were treated as in the negotiations and organizations as though they were Great Powers. British power, however, had declined to such an extent as to be distinctly inferior to that of the United States and the Soviet Union, which in view of their enormous superiority over the power next in rank, deserved to be called Superpowers.

The Second World War ended with the major weight in the balance of power having shifted from the traditional players in the Western and Central Europe to just two non-European ones - the United States and the Soviet Union. This resulted in the emergence a bipolar Cold War international system. Interestingly, the end of the Cold War and the demise of the bipolar world order heralded an era of transition for global governance (Tank, 2012, p.1). The foremost feature of the immediate post-Cold War world was the dominance of the United States, and the transformation into a "unipolar" system of hegemony, where US had the physical resources to pursue its unilateralist foreign policy around the world. Consequently, the era was marked by a fundamental shift in the strategic power balances as a result, a coalition of major powers under the leadership of the US had emerged (Basu (2004, p.382). The US unilateral use of force during this era and other de facto foreign policy endeavours had far-reaching implications on international system in particular and the world at large.

However, in recent years, US Great Power or Superpower status has been increasingly confronted with the growing influence of countries with potential as Great Powers, resulting to a polycentric balance of power or, in less elegant phraseology, multipolarity. This study identifies states that vie for Great Power status in the contemporary world politics and explore relative indices for their quest for such status. The paper also examines the implication of these, particularly emerging powers to the world system and survival of humanity.

\section{CONCEPTUAL DISCOURSE}

Although Great Power systems existed long before the Great Power role was institutionalized at the Congress of Vienna and before the International Law was formally codified at the Peace of Westphalia, nearly all definitions of the concept primarily focus on military might as well as waging and winning wars. Taylor (1954, p.xxiv), for example, asserts that "the test of a Great Power is the test of strength of war". Modelski (1972, p.149) opines that a Great Power "must be capable of fighting a major war" while Singer and Cusack (cited in Levy, 1983) insist that the obvious attribute of a major power is the "ability to wage war frequently and to win most of those wars. From the standpoint of Wight (1978, pp.52-53), there are two sorts of power - a dominant and a Great Power. While a dominant power is a power that can confidently 
contemplate war against any likely combination of other powers, Great Power is a power that can confidently contemplate war against any other existing single power. The classic definition and characterization by Levy $(1983, \mathrm{p} .16)$ is that: a Great Power is a state that plays a major role in the international politics with respect to security-related issues. The Great Powers can be differentiated from other states by their military power, interests, their behaviour in general and interactions with other powers, other powers' perception of them and some formal criteria. The criteria, according to Heywood (2015, p.86), are military prowess, economic clout, have global sphere of interest, adopt a 'forward' foreign policy and have actual impact in international affairs. Waltz (1979, p.131) corroborates the above viewpoint when he asserts that "a Great Power is a state which excels in size of population and territory, resource endowments, economic capability, military strength, political stability and competence". Therefore, latter criterion derived from Ranke (1950, p.203) celebrated sentence is that a Great Power "must be able to maintain itself against all others, even when they are united". In other words, Great Powers must have possessed capabilities sufficient to defend itself against a combination of all other states.

From the standpoint of Jackson (2000, p.85), a Great Power is 'a state whose weight (in military power, in political prestige, in economic wealth) is of such magnitude that it is among a very selected group of states whose policies and actions can affect the course of international affairs'. The definition of Great Power given by Heywood (2011, p.7) is all-encompassing and instructive. According to him, a Great Power is a state deemed to rank amongst the most powerful in a hierarchical state-system. Therefore, the four determinant of a great power are: First, Great Powers are in the first rank of military prowess, having the capacity to maintain their own security and, potentially, to influence other powers. Second, they are economically powerful states. Third, they have global, and not merely regional, spheres of interests. Fourth, they adopt a 'forward' foreign policy and have actual, and not merely potential, impact on international affairs. In a similar vein, the term hegemony (from the Greek hegemonia meaning 'leader') is, in its simplest sense, the leadership or domination of one element of a system over others. Italian Marxist and social theorist Antonio Gramsci (cited in Heywood, 2011, p.71) used the term to refer to the ideological leadership of the bourgeoisie over subordinate classes. Gramsci insisted that bourgeois hegemony could only be challenged at the political and intellectual level, through a 'counter-hegemonic' struggle, carried out in the interests of the proletariat and on the basis of socialist principles, values and theories.

In international politics, a hegemon is the leading state within a collection of states. Hegemonic status is based on the possession of structural power, particularly the control of economic and military resources, enabling the hegemon to shape the preferences and actions of other states, typically by promoting willing consent rather than through the use of force. Following Gramsci, the term implies that international or global leadership operates, in part, through ideational or ideological means (Heywood, 2011, pp.221). Finally, the major powers are usually specified through one or more defining elements. First, the power dimension reflecting the sheer size of a nation's capabilities; second, the spatial dimension that refers to geographic scope of interests, actions, or projected power; and third, the status dimension indicating a formal or informal acknowledgment of the major power status (Danilovic, 2002, pp.28).

\section{THEORETICAL FRAMEWORK}

This study adopts Realism (known variously as "political realism" "Realpolitik" and "power politics") as a framework of analysis. The theory remains one of the oldest and most frequently adopted approaches to international politics, although revised versions and competing approaches have emerged which attempt to provide better explanations for a complex and rapidly changing world. Realism is often portrayed as a tradition of thought that date back as 
far as the great Greek historian - Thucydides, the chronicler of the ancient Peloponnesian Wars who wrote, "the strong do what they have the power to do, the weak accept what they have to accept" (Thucydides, 1972:402; Griffiths \& O'Callaghan, 2007:54-63). Some of the main proponents of realism and their most influential works are: Niccolo Machiavelli, The Prince (first published in 1532), Thomas Hobbes, Leviathan (1651), E. H. Carr, The Twenty Years' Crisis (1939); Georg Schwarzenberger, Power Politics (1951, first published in 1941), Martin Wight, Power Politics (1946); Hans J. Morgenthau, Politics Among Nations (1967, first published in 1948), and George F. Kennan, American Diplomacy (1951), among others. These writers represent the attempt of an entire generation to understand and express their most fundamental beliefs about international politics with emphasis on power. For instance, the Machiavellian strategies or game plans for state power and the Hobbessian rationale of government power in the state of anarchy. Morgenthau, however, articulated the significance of national interest and state power in modern international politics (Haque, 2004, pp.145165). Therefore, being the platinum coin of the international realm, the power of states has been treated as the most important concept in the study of world politics.

An influential realist scholar John Mearsheimer (2001, pp.29-32; 2004, pp.179-197), contends that Great Powers always seek to maximize their share of world power, and all Great Powers seek hegemony in the international system. The explanation for why Great Powers vie with each other for power and strive for hegemony is derived from a number of assumptions about the international system. The first assumption of the realist school is that the international system is anarchic, which does not mean that it is chaotic or riven by disorder or a world characterized by security competition. It implies that the international system comprises independent states that have no central authority above them (Waltz, 1979, pp.88-93; Art \& Jervis, 1973, p.1; Milner, 1991, pp.67-85). Sovereignty, in other words, inheres in states because there is no higher ruling body in the international system (Fischer, 1992, pp.427-466). There is no "government over governments." (Claude, 1971, p.14; Mearsheimer 1994/95, pp.9-10; 2001). Therefore, the Great Powers framework shares this basic assumptions of the realist paradigm of international politics but focuses explicitly on the small number of the leading actors in the international system. It is assumed that in an anarchic international system, there exists a hierarchy of actors determined on the basis of power. According to Levy (1983, pp.8-10), since the emergence of the modern system, the dominant actors have been nation-states and the more powerful states - the Great Powers determined the structure, major processes, and general evolution of the system. From 1815, the Great Powers assumed a privileged status that undermined the formal sovereign equality that had prevailed in the previous century and enabled them to set norms and lay down rules for international society as a whole (Armstrong, 1999, pp.547-562). Consequently, the action and interactions of the Great Powers are of primary interest. Secondary states and other actors have an impact on the system largely to the extent that they affect the behaviour of the Great Powers. This hierarchy of actors is intimately related to a hierarchy of issues dominated by military security.

The second assumption is that great powers inherently possess some offensive military capability, which gives them the wherewithal to hurt and possibly destroy each other. States are potentially dangerous to each other, although some states have more military might than others and are therefore more dangerous. Thus, a state's military power is usually identified with particular weaponry at its disposal, although even if there were no weapons, the individuals in those states could still use their feet and hand to attack the population of another state (Mearsheimer, 2014, p.179). This implies that material inequality reduces the number of effective players in the international system. But unless one is clearly superior to all others, the Hobbesian logic will reassert itself in relations among the strong. 'Great Power' states with the capacity to inflict punishing damage, even the threat of death, on any 
other power in the system are equals. This suggests that realism is a theory of great power politics, rather than a general theory of international relations. Paradoxically, relations between fundamentally unequal powers would be governed by another logic of interaction (Donnelly, 2005, pp.2-54).

The third assumption is that states can never be certain about other states' intentions. Specifically, no state can be sure that another state will not use its offensive military capability to attack the first state. This according to Mearsheimer is not to say that states necessarily have hostile intentions. Indeed, all of the states in the international system may be reliably benign, but it is impossible to be sure of that judgement because intentions are impossible to divine with 100 per cent certainty. As Mearsheimer (2001, pp.29-32) note, there are many possible causes of aggression, and no state can be sure that another state is not motivated by one of them. Furthermore, intentions can change quickly, so a states' intentions can benign one day and hostile the next. However, uncertainty about intentions is unavoidable, which means that states can never be sure that other states do not have offensive intentions to go along with their offensive capabilities.

The fourth assumption is that survival is the primary goal of great powers. Specifically, states seek to maintain their territorial integrity and the autonomy of their domestic political order. Survival dominates other motives because, once a state is conquered, it is unlikely to be in a position to pursue other aims. Clearly then, States can only pursue other goals, of course, but security is their most importantly objective. The fifth assumption is that great powers are rational actors. They are aware of their external environment and they think strategically about how to survive in it. In particular, they consider the preferences of other states and how their own behaviour is likely to affect the behaviour of those other states, and how the behaviour of those other states is likely to affect their own strategy for survival. Moreover, states pay attention to the long term as well as the immediate consequences of their actions (Mearsheimer, 2001, p.31).. Of note, none of these assumptions alone dictates that great powers as a general rule should behave aggressively toward each other. There is surely the possibility that some state might have hostile intentions, but the only assumption dealing with a specific motive that is common to all states says that their principal objective is to survive, which by itself is a rather harmless goal. Nevertheless, when the five assumptions are married together, they create powerful incentives for great powers to think and act offensively with regard to each other. In particular, three general patterns of behaviour result: fear, self help, and power maximization (Mearsheimer, 2001, p.30). In essence, great powers are trapped in an iron cage where they have little choice but to compete with each other for power, in the international system, if they hope to survive.

\begin{abstract}
ANALYSIS
The contemporary international system best described as the "post-Cold War" international system (Eminue, 2012, p.206) had two phases. The first lasted from December 31, 1990, until September 11, 2001. The second lasted from 9/11 till now. According to Friedman (2013), the initial phase of the post-Cold War world was built on two assumptions. The first is that the United States was the dominant political and military power. The second revolve around the three Great Powers - the United States, China and Europe. Currently, countries such as Russia, Germany, and France are potential Great Powers.
\end{abstract}

The United States of America, with the population of 326,298,777 as at April, 2018 (based on United Nations estimates) and GDP of $\$ 18.6$ trillion established itself as a great power in the early 20th century. America's economic dynamism enabled it to become pivotal in both regional and world politics (Brzezinski, 1997, p.4). The path was forged through continuous 
application of US's growing power; hard and soft alike. According to Nye (2004), while hard power is one that involves the use of military and economic power to influence or control the behaviour or interests of other states or political groups, soft power is a persuasive approach to international political relations, involving the use of a nation's cultural, historical and diplomatic influence. Consequently, America shaped its regional milieu to best serve security and material ends. However, the immediate post-Cold War environment and early 2000s witnessed a degree of American power, financial, economic and military, that led critics to complain about the existence of a hyper-power, a critical variant on the term 'superpower' (Black, 2008, p.169). Put differently, American global power - military, economic, technological, cultural, and political was one of the great realities. According to Sapolsky (2009), American military at the end of the Cold War was a formidable force, large in size, very well equipped, and quite capable of meeting any conceivable warfare challenge, nuclear or conventional. Currently, American military is ranked number one with pwrlndx rating of 0.0818. The US spends 3.3\% of its GDP on military expenditures. Consequently, American economic growth, financial strength and geo-political ambitions contributed to belief in a new military system and process of military change that would enable the US to remain the leading power and achieve its goals without the traumas of major war.

Similarly, Russia is the world's largest country by land mass, nearly twice as big as Canada, the world's second-largest nation - and covers all of northern Asia and much of Eastern Europe. It shares land borders with more than a dozen countries, and shares sea borders with Japan and the United States. Following the dissolution of the Soviet Union, Russia turned into an aggrieved colossus - anxious to restore its status as a world power. Consequently, Russian foreign policy has been essentially guided by the desire to reaffirm its great power status and emergence as an energy superpower centred on the export of oil and gas (Rich, 2009). With the population 144.3 million and GDP of $\$ 1.3$ trillion, Russia is ranked second militarily. It spends $5.4 \%$ of its GDP on military expenditures. As observe by Adelman (2017), Putin has rebuilt Russia's military capability by spending $\$ 49 \mathrm{~B}$ a year on security. Russia retains 1,790 strategic nuclear weapons and with over 140 million people. Russia has one of the world's largest economies that is powered by its extensive natural resources. Top industries include oil and natural gas production, with agriculture, forestry, fishing and manufacturing serving as other economic drivers. Oil and natural gas, in particular, represent large portions of the country's economy.

In a related development, since the Cold War, China with the population of 1.4 billion has been an important impetus in the transition. The country's economic rise has been drastically changing the world's economic balance, and China's "great power" strategy is fundamentally reshaping the world's political landscape. As Xinbo (2016) note, China's "great power" strategy is reflected in geographical and psychological objectives. Geographically, China has actively promoted development in both land and sea, based on its geopolitical strategy and geoeconomic environment. On land, China has strengthened economic ties with Eurasia via the Belt and Road initiative, and, while deepening cooperation with developed economies in Western Europe, actively tap the potential of Central Asia, South Asia, East Asia and Central and Eastern Europe. At sea, China should intensify economic connections with Pacific Rim countries, especially the US and Japan, via the Regional Comprehensive Economic Partnership, Free Trade Area of the Asia Pacific and other bilateral and multilateral arrangements. Interactions with the US and Japan are of vital importance for China's economic transformation. China's economy is the world's second- largest, trailing only the United States. China is recognized as possessing nuclear weapons. For Freeman and Macau (2017), China has assumed the historic status as a major source of the world's new technology, joining Japan and south Korea in this role. Militarily, China is the 3rd with 0.0852 rating and spends $1.9 \%$ of its 
GDP on military expenditures. According to Adelman (2017), China, with its ten trillion dollar GDP, over two trillion dollars of exports, over three trillion dollars in its reserve fund, 1.35 billion people and 3.7 million square miles of territory, is a future great power.

Also, Britain is one of the standard case studies in great power politics. It is a leading member of all the key international organizations, notably the North Atlantic Treaty Organization (NATO), the UN Security Council (on which it has veto power), the G-8 group of major economic powers and recently opted out of the European Union. Once one of the world's great powers (McCormick, 2007:82), and with the population of 66.57 million according to the most recent UN estimates, it is one of the most successful and dynamic economies in Europe. In economic terms, Britain has all the typical features of a post-industrial free-market-society. Economic growth - combined with a downturn in the fortunes of some countries has helped make Britain the fourth biggest economy in the world with a GDP figure in the first quarter of 2018 of $\$ 476,050$ million, leaving United Kingdom placed 4th in the ranking of quarterly GDP of the 50 countries. Militarily, United Kingdom is ranked 6 (out of 136) out of the countries currently considered for the annual GFP review. It holds a PwrIndx rating of 0.1917. In terms of arms spending it is $2 \mathrm{nd}$ or $3 \mathrm{rd}$ in terms of Countries that project power externally (Thompson, 2017). Similarly, Germany population density is 227.9 people per square kilometer $(590.2 / \mathrm{mi} 2)$ as of June 2018 . Density of population is calculated as permanently settled population of Germany divided by total area of the country. Total area is the sum of land and water areas within international boundaries and coastlines of Germany. The total area of Germany is $357,021 \mathrm{~km} 2(137,847 \mathrm{mi} 2)$ according to the United Nations Statistics Division. The economy of Germany is a highly developed social market economy. It has the largest national economy in Europe, the fourth-largest by nominal GDP in the world, and fifth by GDP (PPP). In 2017, the country accounted for $28 \%$ of the euro area economy (IMF News, 2017). Germany is ranked 10 (out of 136) out of the countries currently considered for the annual GFP review. It holds a PwrIndx rating of 0.2461. The Gross Domestic Product (GDP) in Germany was worth 3466.76 billion US dollars in 2016. The GDP value of Germany represents 5.59 percent of the world economy.

In summary, since the $21^{\text {st }}$ century, US has remained a leading country in terms of capabilities. For instance, in the early years of 2000s, the US spent 295 billion on its military budget, and Russia and China combined spent 100 billion. In fact, American military spending, which had been 276 billion in 1998, had risen to 310 billion, which was more than the next nine largest national military budgets combined, although American economic growth ensured that this was only half of the percentage of GDP spent under Reagan. For 2002, American expenditure was about 40 per cent of the world's total military spending (Black, 2008, p.169). This development, reinforced the unilateral tendencies exhibited by the only surviving Superpower in the world in carrying out regime change in Afghanistan to overthrow the Taliban Government after the September 11, 2001 terrorist attack on the US and in Iraq in 2003 to remove Saddam Hussein from power without the approval of the UN Security Council and without support from its major transatlantic alliance partners - France, Germany, etc (Eminue, 2012, p.206; Ezirim \& Dickson, 2012, p.154). From the perspective of great power responsibility, Aslam (2013) concluded that American foreign policy actions, particularly the US invasion of Iraq in 2003, American drone attacks in Pakistan and the practice of extraordinary rendition are examples of irresponsible actions undertaken by the US acting as a great power in the international system.

\section{CONCLUSION}

From the analysis above, the study concludes with an observation that the United States remains the most powerful country on earth. America's dynamic economy, ever-increasing 
population, and its overwhelming military superiority, technological development all ensure that the United States sits secure in its status on top of the greasy pole of international power politics. However, in recent past, China cemented its status as the world's second greatest power and the greatest long-term challenger to the United States. In the face of American passivity, Beijing projected power in the South and East China Seas, built up its artificial outposts and snatched a US military drone. Clearly, Russia and China are the next two major powers and are among the world's top nations in terms of military capabilities, and economic clouts. Following the top three are Germany, United Kingdom, France and Japan - countries that have large military capability, technology, economies, and give out high numbers of international aid. Consequently, the international system is undergoing a fundamental transformation with the emergence of more great powers. The emergence of multiple great powers will ensure global stability as international cooperation is more conditioned by the relationships between the great powers.

\section{References}

Adelman, J. (2017). Thinking the unthinkable: Russia has re-emerged as great power. Retrieved from https://www.huffingtonpost.com.

Armstrong, D. (1999). Law, justice and the idea of world society. International Affairs, 75(3), 547-562.

Art, R. J. \& Jervis R. (Eds.) (1973). International Politics: Anarchy, Force, Imperialism, Boston: Little, Brown.

Aslam, W. (2013). The United States and Great Power Responsibility in International Society: Drones, rendition and invasion. New York: Routledge.

Basu, R. (2004). The United Nations: Structure and functions of an International Organisation. Revised Edition. New Delhi: Sterling Publishers Private Ltd.

Bridge, F. R. \& Bullen, R. (2005). Great Powers and the European States System, 1918 - 1914. Second Edition. Harlow, England: Pearson Longman.

Buzan, B. \& Little, B. (1999). Beyond Westphalia? Capitalism after the Fall, In M. Cox, K. Booth and T. Dunne (Eds.) The Interregnum: Controversies in World Politics 1989 - 1999. Cambridge, New York: Cambridge University Press, pp. 89-104.

Carr, E. H. $(1939,1964)$. The Twenty Years' Crisis, New York: Harper and Row.

Claude Jr, I. L. (1971). Sword into Plowshares: The Problem and Progress of International Organization, 4th Edition. New York: Random House.

Danilovic, V. (2002). When The Stakes are High: Deterrence and Conflict among Major Powers, Ann Arbor: The University of Michigan Press.

Donnelly, J. (2004). Realism and International Relations, Cambridge: Cambridge University Press.

Eminue, O. (2012). International System and its Actors: An Appraisal In: A. E. Ekpe, M. B. Abasiattai and O. Akpan (Eds.). An Introduction to International Studies and World Politics. Yaounde: Book House, pp.201-241.

Ezirim, G. E. and Dickson, M. (2012). Unilateralism and the United States' use of Force in the Post-Cold War World: A Critique. Nigerian Journal of Social Sciences, 8(2):147-159

Fischer, M. (1992). Feudal Europe, 800 - 1300": Communal discourse and conflictual practices, International Organization, 46(2): 427-466

Griffiths, M. \& O' Callaghan, T. (2007). Realism, In R. Devetak, A. Burke and J. George (Eds.). An Introduction to International Relations: An Australian Perspectives. Cambridge: Cambridge University Press, pp. 54-63.

Haque, M. S. (2004). The Revival of Realism in International Politics after September 11 and its Ethical Impact. In M. Evans (ed.). Ethical Theory in the Study of International Politics. New York: Nova Science Publishers, Inc, pp. 145-165.

Heywood, A. (2011). Global Politics. New York: Palgrave Macmillan.

Heywood, A. (2015). Key Concepts in Politics and International Relations. Second Edition. London: Palgrave.

IMF News (2017). Economy of Germany. Retrieved http://www.imf.org/en/News/Articles/2017/07/05/na070717. 
Jackson, R. (2000). The Global Covenant: Human Conduct in a World of States, Oxford: Oxford University Press. Kennan, G. F. (1951) American Diplomacy, 1900 - 1950, Chicago: University of Chicago Press.

Mearsheimer, J. J. (2001). The Tragedy of Great Power Politics. New York, London: W.W. Norton \& Company. (2014). Anarchy and Struggle for Power. In, C. Elman and M. A. Jensen (eds.). Realism Reader. London, New York: Routledge.

Milner, H. (1991). The Assumption of Anarchy in International Relations Theory: A Critique, Review of International Studies, 17(1): 67-85

Morgenthau, H. J. (1946). Scientific Man versus Power Politics. Chicago: University of Chicago Press.

Morgenthau, H. J. (1948). Politics Among Nations: The Struggle for Power and Peace. New York: Alfred A. Knopf. Morris, J. (2011). How Great Britain? Power Responsibility and Britain's future Global Role. BJPIR, 13(3): 326-347. Nadkarni, V. (2013). Introduction In, V. Nadkarni and N. C. Noonan (eds.), Emerging Powers in Comparative Perspective: The Political and Economic Rise of the BRIC Countries. New York, London: Bloomsbury, pp. 1-21.

Nye, J. S. (2004). Soft Power: The Means to Success in World Politics. New York, N.Y.: Public Affairs.

Osterud, O. (1992). Regional Great Power In, I. B. Newmann (ed.). Regional Great Powers in International Politics. London: Macmillan Press, pp. 1-15.

Rich, P. B. (2009). Russia as a Great Power. Small Wars and Insurgencies, 20:2,276-299.

Saposky, H. M. (2009). US Military Doctrines sine the Cold War. Retrieved https://www.e.ir.info.2009/05/06/usmilitary-doctrine-since-the-cold-war.

Schwarzenberger, G. (1941). Power Politics, New York: Prager.

Simpson, G. (2004). Great Powers and Outlaw States: Unequal Sovereign in the International Legal Order. Cambridge: Cambridge University Press.

Spykman, N. (1942). America's Strategy in World Politics: the United States and the Balance of Power, New York: Harcourt, Brace \&World.

Tank, P. (2012). The Concept of Rising Power. Norwegian Peace-building Resource Centre. p.1.

Thompson, S. (2017). Is British still a World Power? Retrieved https://www.quora.com.

Waltz, K. N. (1979). Theory of International Politics. New York: Random House.

Watson, A. (2009). The Evolution of International Society: A Comparative Historical Analysis. London, New York: Routledge.

Wight, M. (1964). Power Politics, London: Royal Institute of International Affairs.

Archer, Clive (2001). International Organizations, Third Edition. London and New York: Routledge.

Holsti, K. J. (1995). International Politics: A Framework for Analysis. New York: Routledge.

Modelski, G. (1961) Agraria and Industria: Two models of the International System. In Knorr, Klaus \& Verba, Sidney (eds.).The International System: Theoretical Essays. London: Palgrave.

Ranke, L. (1950). The Great Powers, In, T. H. von Laue, Ranke (eds.) The Formative Years. Princeton, NJ: Princeton University Press.

Schuman, F. L. (1933). International Politics, New York: McGraw-Hill. 